\title{
STAN ZACHOWANIA DWORKU MARII KONOPNICKIEJ W GUSINIE W KONTEKŚCIE JEGO POTENCJALNEJ REWITALIZACJI
}

\begin{abstract}
Zarys treści: W położonej niedaleko Uniejowa wsi Gusin (obecnie gmina Świnice Warckie w powiecie łęczyckim) znajduje się niewielki dworek szlachecki, w którym w latach 70. XIX wieku zamieszkiwała wraz z rodziną Maria Konopnicka. Informacje o szczególnym znaczeniu dla dziedzictwa kulturowego, obiektu związanego z biografią Konopnickiej można znaleźć w przewodnikach i w opisie map turystycznych, jak również na portalach samorządowych w działach prezentujących miejscowe atrakcje turystyczne. Może to zachęcać do jego zwiedzania. Tymczasem, jak wykazała wizja lokalna przeprowadzona przez autorów, budynek znajduje się obecnie w bardzo złym stanie technicznym, zagrażającym wystąpieniem katastrofy budowlanej. Stwierdzono, że bez podjęcia szybkich kroków mających na celu powstrzymanie dalszej rujnacji dworku, w ciągu kilku lat ulegnie on nieodwracalnej degradacji.
\end{abstract}

Słowa kluczowe: Maria Konopnicka, Gusin, degradacja budynków, ochrona zabytków kultury materialnej

\section{WPROWADZENIE}

Utrzymanie przez gminę Uniejów pozycji wiodącego w Polsce centralnej ośrodka usług turystycznych wymaga ciągłej rozbudowy oferty turystycznej i zwiększania jej atrakcyjności ${ }^{1}$. To niewielkie miasteczko i jego okolice, z uwa-

* Marcin Gorączko, dr, Katedra Ekoinżynierii i Fizykochemii Środowiska, Wydział Budownictwa, Architektury i Inżynierii Środowiska, Uniwersytet Technologiczno-Przyrodniczy w Bydgoszczy, ul. Prof. S. Kaliskiego 7, 85-789 Bydgoszcz, e-mail: gorgon@utp.edu.pl.

** Aleksandra Gorączko, dr inż. Katedra Geomatyki, Geotechniki i Zagospodarowania Przestrzennego, Wydział Budownictwa, Architektury i Inżynierii Środowiska, Uniwersytet Technologiczno-Przyrodniczy w Bydgoszczy, ul. Prof. S. Kaliskiego 7, 85-789 Bydgoszcz. e-mail: agora@utp.edu.pl.

1 M. Gorączko, A. Gorączko, Raport z analizy potencjału turystyczno-kulturowego powiatu poddębickiego, „Turystyka Kulturowa” 2016, 6, s. 125-145. 
gi na gorące źródła, co roku odwiedzane są przez kilkaset tysięcy przyjezdnych. Można mówić w tym przypadku o spektakularnym sukcesie gospodarczym i wizerunkowym. Obecnie głównym celem władz samorządowych jest zachęcanie turystów do dłuższych i bardziej urozmaiconych pobytów, także poza wysokim sezonem, czemu służy profesjonalizacja oferty turystycznej. W tym kontekście można się spodziewać, że znaczną rolę w niedalekiej przyszłości do odegrania będą miały walory kulturowe, a przez to historycznie powiązanych z Uniejowem.

Dużym potencjałem z punktu widzenia turystyki kulturowej cechują się miejsca związane z biografią Marii Konopnickiej, która w rejonie Uniejowa spędziła kilkanaście lat swojego życia ${ }^{2}$. Pierwszym z nich jest Bronów w gminie Wartkowice, gdzie w murowanym dworku od 1995 roku znajduje się Muzeum Oświatowe im. Marii Konopnickiej, poświęcone życiu i twórczości poetki. Obiekt promowany, jako „Dworek Marii Konopnickiej”, w rzeczywistości został wzniesiony dopiero w 1902 roku, na miejscu dawnej modrzewiowej siedziby Konopnickich, przez nowego właściciela majątku Artura Dzierzbickiego. Urodzona w Suwałkach, wychowana w Kaliszu oraz w Warszawie, Maria Konopnicka z domu Wasiłowska, sprowadziła się do Bronowa w 1862 roku, po poślubieniu Jarosława Konopnickiego, zarządzającego kluczem dóbr rodzinnych, w skład których wchodziły wsie Konopnica, Bronówek oraz właśnie Bronów. W Bronowie Maria Konopnicka wiodła typowe życie żony ziemianina. Tutaj przyszły na świat jej dzieci. Z różnych względów w ciągu kilku lat majątek Jarosława Konopnickiego znacznie podupadł, a w 1872 roku został on sprzedany.

Autentycznym świadkiem ważnych wydarzeń z życia Marii Konopnickiej jest dworek w Gusinie, położonym w gminie Świnice Warckie w powiecie łęczyckim ${ }^{3}$, do którego Konopniccy przenieśli się po opuszczeniu Bronowa. Dworek od kilkunastu już lat przedstawiany jest w regionalnych i lokalnych materiałach turystycznych jako obiekt zrujnowany i zaniedbany ${ }^{4}$. Nie został on również jak dotąd objęty ochroną konserwatorskąa, pomimo dużego znaczenia dla narodowego dziedzictwa kulturowego. Mimo tych mankamentów obiekt polecany jest, jako wart odwiedzenia w przewodnikach turystycznych po regionie ${ }^{6}$, znajduje się również na trasie niebieskiego szlaku pieszego im. Marii Konopnickiej, przebiegającej na styku powiatów poddębickiego i łęczyckiego, a sama miejscowość odwiedzana jest dość często przez grupy zorganizowane w trakcie cyklicznych rajdów turystycznych poświęconych pamięci poetki.

2 H. Sławińska, Maria Konopnicka w Bronowie i Gusinie, Wyd. Literatura, Łódź 2003.

3 M. Gorączko, A. Gorączko, Raport z analizy potencjału turystyczno-kulturowego Łęczycy i powiatu łęczyckiego, Turystyka Kulturowa 2016a, 5, s. 165-181.

4 Np. www.zamkilodzkie.pl; Powiat Łęczycki-mapa turystyczna skala 1:60000, Starostwo Powiatowe w Łęczycy.

5 www.kultura.lodz.pl

6 B. Solarski, M. Sęczkowska, A. Prasnowska (red.), Przewodnik po Łęczycy i powiecie łęczyckim, Towarzystwo Miłośników Ziemi Łęczyckiej, Towarzystwo Naukowe Płockie Oddział w Łęczycy, Łęczyca 2000; J. Szymczak (red.), Przewodnik po Łęczycy i regionie tęczyckim, Towarzystwo Miłośników Ziemi Łęczyckiej, Towarzystwo Naukowe Płockie Oddział w Łęczycy, Urząd Miejski w Łęczycy, Starostwo Powiatowe w Łęczycy, Łęczyca 2005. 
Sytuacja ta skłoniła autorów do podjęcia rozpoznania stanu zachowania obiektu, ze szczególnym uwzględnieniem jego stanu technicznego i walorów użytkowych, pod kątem jego ewentualnej rewitalizacji. Powodem zainteresowania się autorów dworkiem w Gusinie był również fakt, iż został on zbudowany z kamienia wapiennego, eksploatowanego w miejscowym kamieniołomie (najprawdopodobniej w rejonie Świnic Warckich'), przez co wpisuje się on w podjętą przez nich już kilka lat temu problematykę tego typu budownictwa w rejonie Kotliny Kolskiej ${ }^{8}$. Obiekt w Gusinie jest ciekawym budynkiem z kamienia także z tej przyczyny, że reprezentuje najwcześniejszą fazę zastosowania materiału skalnego w budownictwie tego regionu, z którego korzystało początkowo głównie ziemiaństwo wznosząc swoje siedziby. Dopiero później praktyka ta upowszechniły się wśród mieszczan, a następnie okolicznego chłopstwa, w kolejnych dekadach rozprzestrzeniając się daleko poza obszar Kotliny Kolskiej.

\section{DZIEJE OBIEKTU W ZARYSIE}

Dworek w Gusinie został wzniesiony około 1840 roku w obrębie majątku o powierzchni 40 ha, stanowiącego część dóbr donacyjnych Ambrożew hrabiego Sołłohuba. Na jego wydzierżawienie zdecydował się Jarosław Konopnicki, po upadku majątku rodowego w Bronowie w 1872 roku. Trwający pięć lat pobyt Marii Konopnickiej w Gusinie okazał się przełomowy w jej życiu, a w konsekwencji dla polskiej kultury. Pierwsze próby poetyckie podejmowała Konopnicka, która dzięki wytrwałej pracy samokształceniowej intelektualnie i światopoglądowo wyrosła znacznie ponad swoje otoczenie, w okresie bronowskim. Powstające już w nowym miejscu zamieszkania utwory cechowała jednak zdecydowanie większa dojrzałość. W Gusinie powstały liczne wiersze drukowane w stołecznych pismach takich jak „Tygodnik Ilustrowany”, „Bluszcz” i „Kłosy”. Tutaj także w roku 1876 powstał poemat „W górach”, którego inspiracją był pobyt poetki w Pieninach latem 1875 roku. Utwór ten został entuzjastycznie przyjęty przez początkującego, ale już rozpoznawalnego na salonach warszawskich literata i dziennikach Henryka Sienkiewicza, co wyraził w przychylnej recenzji opublikowanej w „Gazecie Polskiej”. Ten jednoznaczny dowód uznania dla jej twórczości ośmielił poetkę do podjęcia decyzji o opuszczeniu Gusina. Już w Bronowie narastał konflikt pomiędzy małżonkami, ponieważ Jarosław „nie znajdował zrozumienia dla literackich ambicji żony. W późniejszych latach rozdźwięk ten uległ nasileniu. Jesienią 1877 roku Maria Konopnicka opuściła męża przenosząc się wraz z szóst-

7 Stownik geograficzny Królestwa Polskiego i innych krajów słowiańskich 1890, Tom XI (Sochaczew-Szlubowska Wola), s. 707.

8 M. Gorączko, A. Gorączko, Cechy regionalne w budownictwie na terenie gminy Uniejów, „Biuletyn Uniejowski” 2013, 2, s. 53-65; M. Gorączko, A. Gorączko, Vernacular architecture and traditional rural landscape in new socio-economic realities - a case study from central Poland, „Bulletin of Geography. Socio-economic Series” 2015, no. 30, s. 43-57. 
ką dzieci do Warszawy. Wydarzenie to upamiętniła w wierszu Przed odlotem. Jarosław Konopnicki mieszkał w Gusinie przez następne dziesięć lat, a w 1887 roku przeniósł się do wydzierżawionego majątku w Górze w powiecie sieradzkim. Kolejną właścicielką majątku w Gusinie, do czasów powojennych, była hrabina Ledóchowska, a następnie kilku prywatnych właścicieli. Z zachowanych materiałów archiwalnych oraz informacji uzyskanych od miejscowej ludności wynika, że dworek nadawał się do zamieszkania jeszcze w latach 80 . XX wieku. $\mathrm{Z}$ całego folwarku do chwili obecnej pozostała zaledwie trzyhektarowa resztówka wraz ze zrujnowanym dworkiem. Właścicielem posesji wraz z dworkiem jest obcokrajowiec. Przy polnej drodze prowadzącej do zabudowań znajduje się obelisk pamiątkowy (ryc. 1) poświęcony pobytowi Marii Konopnickiej, ustawiony w 2007 roku staraniem harcerzy z Hufca Uniejów im. Marii Konopnickiej, radnych gminy Świnice Warckie oraz parafii Grodzisko, do której należy wieś Gusin - odsłonięty przez praprawnuczkę poetki Marię Rajpold.

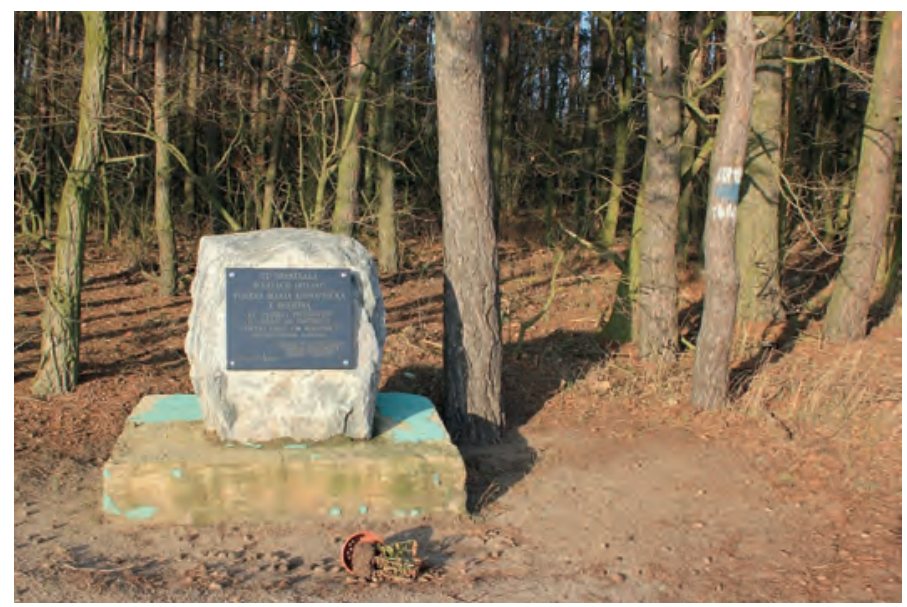

Ryc.1. Pomnik upamiętniający pobyt Marii Konopnickiej w Gusinie (fot. M. Gorączko, 2016)

\section{WYNIKI WIZJI LOKALNEJ}

Wizje lokalne dworku w Gusinie (ryc. 2) oraz jego najbliższego otoczenia przeprowadzono w listopadzie oraz grudniu 2016 roku. Znajduje się on na działce nr 121/2 w obrębie geodezyjnym Świnice Kolonia, o powierzchni ok. 3,3 ha. Większa jej część jest zadrzewiona. Do dworku od strony północnej i wschodniej przylegają pozostałości zdziczałego parku przydworskiego. Z pozostałych stron od drzew dzieli go zadarniona polana. W części południowo-zachodniej posesji występuje las sosnowy. Od strony północno-wschodniej budynek sąsia- 
duje z zarośniętą niecką dawnej sadzawki. Z ukształtowania wynika, że w jej obrębie występowała niewielka wysepka. Według ludowych przekazów było to ulubione miejsce Marii Konopnickiej. Na działce znajdują się również pozostałości zabudowań inwentarskich wzniesionych, podobnie jak sam dworek, z kamienia wapiennego.

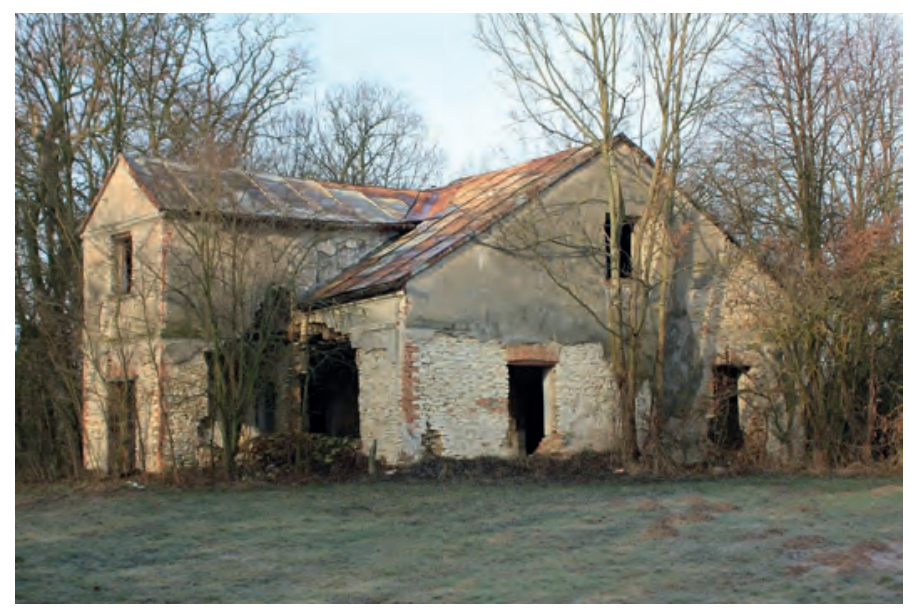

Ryc. 2. Dworek Marii Konopnickiej w Gusinie widok ogólny od strony południowo-wschodniej

(fot. M. Gorączko, 2016)

Dworek jest budynkiem parterowym, wzniesionym na planie prostokąta o wymiarach 10,5 x 11,5 m (ryc. 3), z poddaszem pełniącym funkcję strychu, nakrytym dwuspadowym dachem, obecnie krytym blachą. Prosty kształt bryły urozmaica nieco wysunięty od frontu dwukondygnacyjny ryzalit oraz przyległa do budynku od strony północno-zachodniej przybudówka gospodarcza, także przykryte dachami dwuspadowymi. Podstawowym materiałem budowlanym jest łupany kamień wapienny, łączony na zaprawę glinianą. Mury zewnętrzne o grubości od 40 do $50 \mathrm{~cm}$ wznoszone były jako dwuwarstwowe, w których warstwa wewnętrzna zbudowana jest częściowo $\mathrm{z}$ cegieł ceramicznych, natomiast zewnętrzna $\mathrm{z}$ kamienia wapiennego. Cegłę ceramiczną zastosowano również przy konstruowaniu nadproży i naroży budynku. Mało staranny sposób obróbki i wiązania kamiennych elementów murowych wskazują, że otynkowanie dworku było działaniem z góry założonym. Wnętrze dworku składa się z czterech izb o powierzchni po około $25 \mathrm{~m}^{2}$ każda, w układzie dwutraktowym. Grubość ścian wewnętrznych wynosi od 20 do $30 \mathrm{~cm}$. Trzon kominowy w budynku zlokalizowany jest centralnie, z wlotami każdej z czterech izb. Wysokość kondygnacji mieszkalnej wynosi 2,60 m, a otworów drzwiowych w świetle $1,80 \mathrm{~m}$. W przybudówce gospodarczej znajdowały się schody prowadzące na poddasze. Stanowi ono jedno rozległe pomieszczenie, nad całością budynku za wyjątkiem części nad wejściem do budynku, które pełniło rolę pomieszczenia mieszkalnego. Więźba dachowa 
składa się z krokwi opartych na ściankach stolcowo-kolankowych o wysokości około $0,5 \mathrm{~m}$ oraz wewnętrznych ściankach stolcowych, wzmocnionych zastrzałami. Strop w budynku jest drewniany, belkowy, wykończony od góry deskami i polepą zaś od spodu podbitką z desek i tynkiem na słomie.

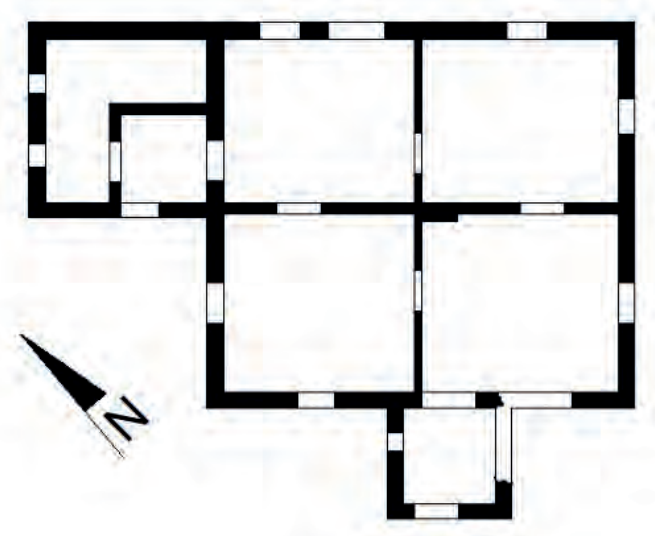

Ryc. 3. Rozplanowanie obiektu

Źródło: opracowanie własne

\section{OCENA STANU ZACHOWANIA OBIEKTU}

$\mathrm{Na}$ podstawie przeprowadzonej wizji lokalnej i wstępnej inwentaryzacji uszkodzeń budynku można stwierdzić, że aktualny stan zachowania obiektu jest bardzo zły i graniczy ze stanem katastrofy budowlanej. Na taką ocenę wpływają przede wszystkim znaczące uszkodzenia ścian zewnętrznych budynku. Konstrukcja murów, zbudowanych w przeważającej części z kamienia wapiennego, częściowo w połączeniu z cegłą ceramiczną jest naruszona przez liczne pęknięcia i ubytki (ryc. 4). Przyczyną tak złego stanu technicznego jest przede wszystkim erozja zaprawy glinianej spomiędzy elementów murowych na powierzchniach ścian, które w znacznym stopniu pozbawione są już oryginalnej wyprawy tynkarskiej. Proces utraty spójności muru jest najbardziej widoczny w miejscach uszkodzonego orynnowania, gdzie woda opadowa, kierowana prosto na lico ścian, wywołała ich przyspieszoną degradację. Utrata spoistości większych fragmentów murów, nawet na całej wysokości ścian, dotyczy zwłaszcza elewacji frontowej w miejscu styku z ryzalitem wejściowym (ryc. 5). Spowodowało to potencjalnie groźną w skutkach utratę podparcia belek stropowych oraz dźwigarów dachowych w tej części obiektu (ryc. 6). Ściana frontowa ryzalitu wejściowego również wykazuje pęknięcia na wysokości obu kondygnacji (ryc. 7). 

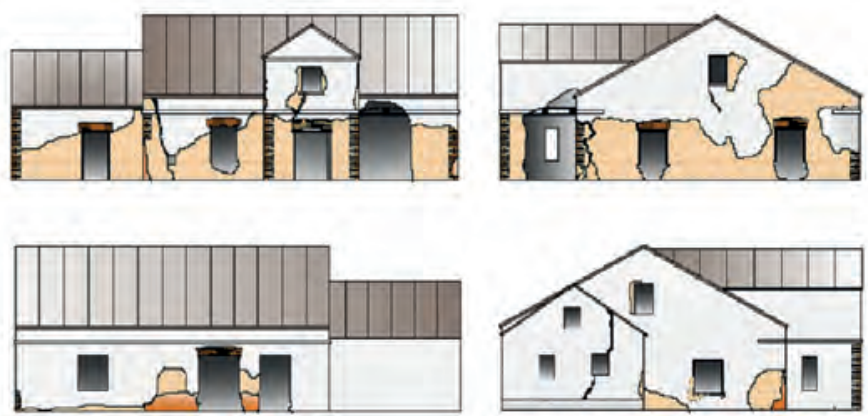

Ryc. 4. Widok elewacji z naniesionymi uszkodzeniami Źródło: opracowanie własne

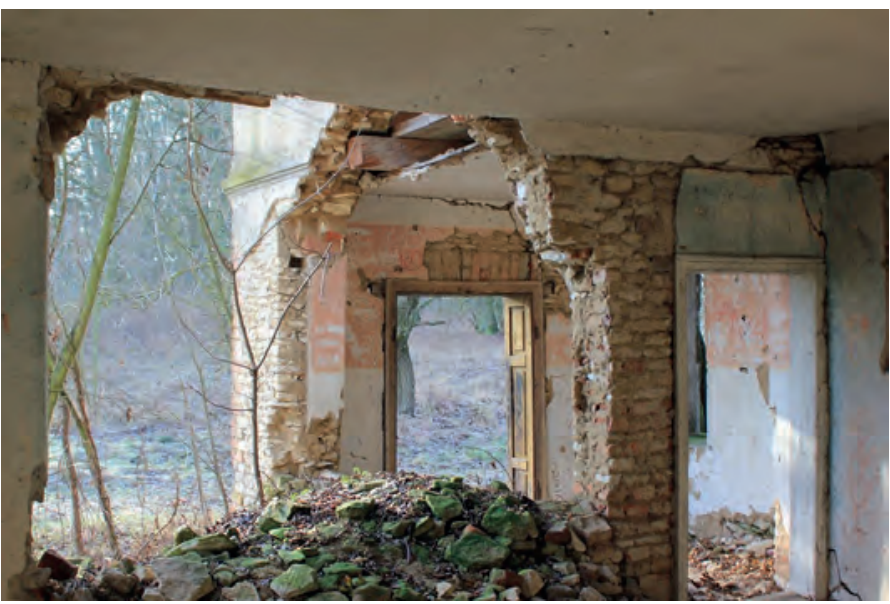

Ryc. 5. Ubytki murów w części frontowej budynku (fot. M. Gorączko, 2016)

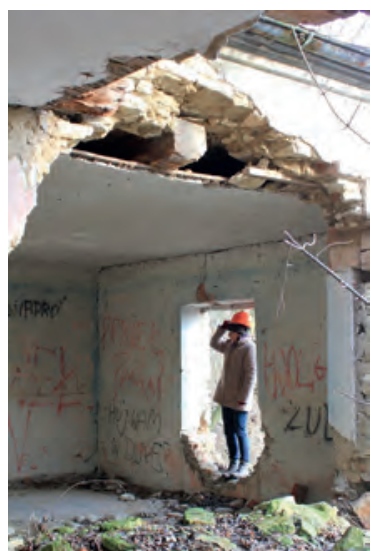

Ryc. 6. Brak podparcia stropu w zrujnowanej części frontowej budynku (fot. M. Gorączko, 2016)

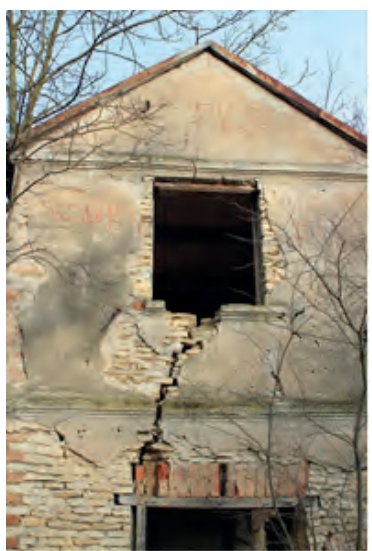

Ryc. 7. Pęknięcie muru w obrębie ryzalitu części frontowej budynku (fot. M. Gorączko, 2016) 
Znaczące pęknięcia murów w narożnikach budynku, o zwiększającej się ku górze rozwartości (ryc. 8), mogą wskazywać także na częściowo geotechniczne przyczyny awarii budynku, związane $\mathrm{z}$ nierównomiernym osiadaniem fundamentów. Budynek zlokalizowano na gruncie piaszczystym o wysokim poziomie wód podziemnych. W kolejnych latach w dolinie Neru, w obrębie której położona jest miejscowość Gusin, wielokrotnie prowadzone były prace melioracyjne

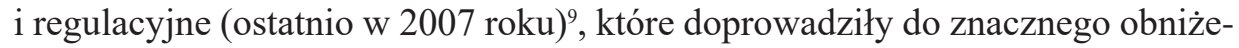
nia poziomu wód gruntowych, czego dowodem jest chociażby zanik pierwotnie znajdującej się w dworskim parku sadzawki.

Proces dekompozycji murów w znacznym stopniu dotyczy również ich części przyziemnych, narażonych na zwiększone zwilgocenie z powodu braku cokołu, a także na skutek intensywnej sukcesji roślinności, rozwijającej się tuż przy budynku (ryc. 9). W tej strefie widoczny jest negatywny wpływ braku właściwego przewiązania warstw konstrukcyjnych muru. Dewastacja stolarki okiennej, zwłaszcza parapetów, zapoczątkowała osunięcie się podokiennych części murów w większości otworów (ryc. 10).

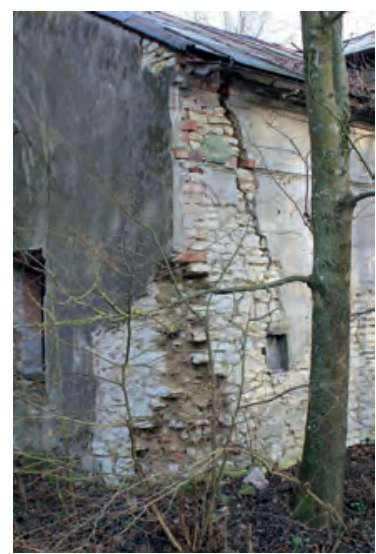

Ryc. 8. Uszkodzenia narożnika budynku (fot. M. Gorączko, 2016)

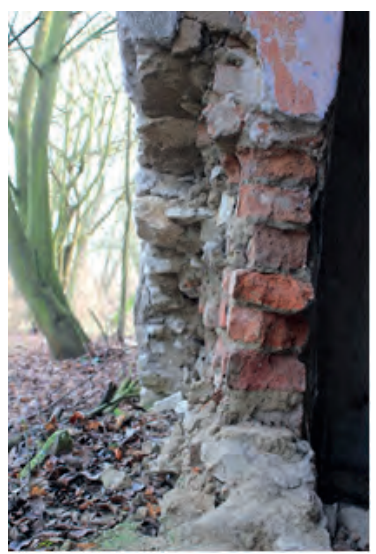

Ryc. 9. Degradacja przyziemnej części muru zewnętrznego

(fot. M. Gorączko, 2016)

Oględziny stanu więźby dachowej pozwalają stwierdzić, że jest ona stosunkowo kompletna, niemniej stopień zużycia materiału jest znaczny. Pokrycie dachu z blachy płaskiej jest ciągłe, niemniej brak części komina nad dachem w części kalenicowej umożliwia penetrację wody opadowej do wnętrza poddasza. Górna powierzchnia stropu nie wykazuje znacznych uszkodzeń mechanicznych, jednak z uwagi na częściowy brak oparcia belek w rejonie zawalonych części frontowych ścian nośnych, jego stateczność jest zagrożona, podobnie zresztą jak stateczność konstrukcji dachu, również pozbawionej podpór w tej strefie.

9 J. Wicher-Dysarz, T. Dysarz, Wstępna prognoza wptywu odmulenia rzeki Ner na warunki hydrauliczne jej koryta, „Acta Sci. Pol., Formatio Circumiectus” 2010, 9 (3), s. 75-82. 
Wnętrze obiektu jest w znacznym stopniu zdewastowane, czego przejawem jest niemal całkowity brak stolarki, wyrwane ze ścian instalacje elektryczne, miejscami uszkodzona podłoga i podbitki sufitowe. Występują liczne pęknięcia ścian wewnętrznych, przede wszystkim na styku z murami zewnętrznymi i w strefie nadproży okiennych i drzwiowych (ryc. 11).

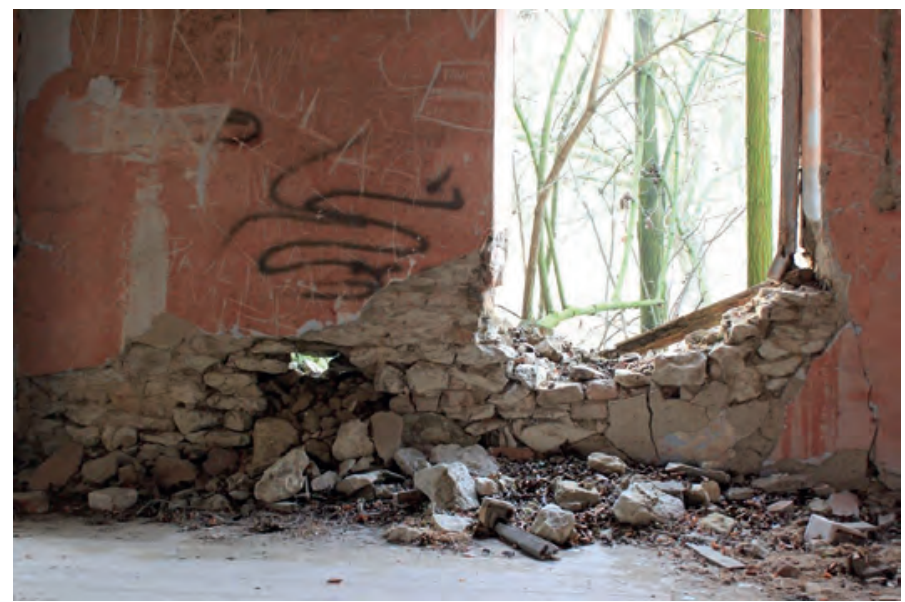

Ryc. 10. Uszkodzenia muru w strefie przyokiennej

(fot. M. Gorączko, 2016)

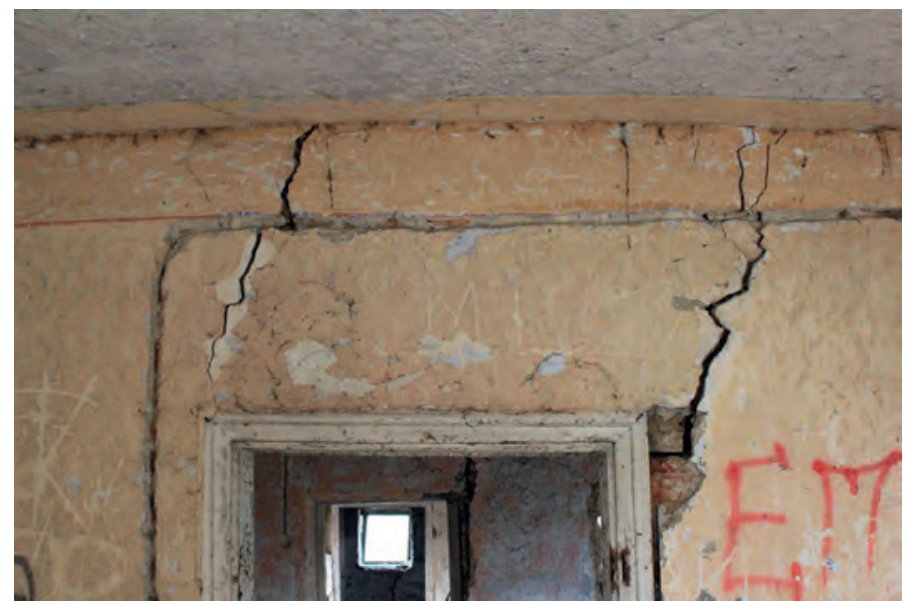

Ryc. 11. Przykładowe uszkodzenia ścian wewnętrznych (fot. M. Gorączko, 2016)

Ściany przybudówki gospodarczej zlokalizowanej przy ścianie północno-wschodniej, mimo zastosowania w tej części cokołu i niemal kompletnie zachowanej wyprawy tynkarskiej, są również wyraźnie popękane. 


\section{PODSUMOWANIE I WNIOSKI}

Dworek Marii Konopnickiej w Gusinie jest potencjalnym celem wycieczki dla turystów przebywających na terenie Uniejowa. Położony w odległości około $14 \mathrm{~km}$ od miasta w linii prostej, jest łatwo osiągalny samochodem w ciągu około 20 minut, rowerem zaś w nieco ponad godzinę. Do jego odwiedzenia zachęcać mogą informacje o dużym znaczeniu obiektu, jako dziedzictwa kultury materialnej o krajowym znaczeniu, zawarte w opracowanych dla regionu przewodnikach i mapach turystycznych, jak również portalach internetowych ${ }^{10}$. W tym kontekście należy wyraźnie podkreślić, że już teraz ze względu na aktualny stan techniczny pustostanu, w każdej chwili grożący zawalaniem, penetracja jego wnętrza jest przedsięwzięciem niezwykle ryzykownym. Co więcej prognozuje się, że ze względu na zainicjowane procesy degradacji podstawowych elementów konstrukcji budynku, stan ten w szybkim tempie będzie się pogarszał. Posesja, na której znajdują się zabudowania dworskie, jest własnością prywatną. Oznacza to, że mimo braku ogrodzenia, wstęp na nią jest nieuprawniony, podejmowany na własną odpowiedzialność.

Odrębną kwestią jest długotrwałe pozostawienie budynku w tak katastrofalnej kondycji. Zgodnie z zapisami prawa budowlanego ${ }^{11}$ na właścicielu obiektu budowlanego ciąży obowiązek utrzymywania go lub jego części w odpowiednim stanie technicznym i estetycznym. W przypadku stwierdzenia, że obiekt budowlany może zagrażać życiu lub zdrowiu ludzi, bezpieczeństwu mienia bądź środowiska, albo jest użytkowany w sposób zagrażający życiu lub zdrowiu ludzi, bezpieczeństwu mienia lub środowisku, lub jest w nieodpowiednim stanie technicznym, powoduje swym wyglądem oszpecenie otoczenia, właściwy organ nakazuje, w drodze decyzji, usunięcie stwierdzonych nieprawidłowości, określając termin wykonania tego obowiązku. Jeżeli nieużytkowany obiekt budowlany nie nadaje się do remontu lub odbudowy, właściwy organ wydaje decyzję nakazującą właścicielowi lub zarządcy jego rozbiórkę i uporządkowanie terenu oraz określającą terminy przystąpienia do tych robót i ich zakończenia. Nie można więc powiedzieć, że władze samorządowe mają w kwestii dalszych losów opisywanego obiektu zupełnie związane ręce. Warto rozważyć możliwość skorzystania z przepisów regulujących kwestie związane z zabezpieczeniem obiektów budowlanych znajdujących się w stanie grożącym zawaleniem, poprzez nakaz umieszczenia na budynku zawiadomienia o stanie zagrożenia bezpieczeństwa ludzi oraz wykonanie doraźnych zabezpieczeń i usunięcie zagrożenia bezpieczeństwa. Należy zwrócić uwagę, że działania te w uzasadnionych przypadkach mogą być podejmowane także w trybie, na koszt właściciela.

${ }^{10}$ B. Solarski, M. Sęczkowska, A. Prasnowska, (red.), Przewodnik po Łęczycy i powiecie łęczyckim, Towarzystwo Miłośników Ziemi Łęczyckiej, Towarzystwo Naukowe Płockie Oddział w Łęczycy, Łęczyca 2000; J. Szymczak (red.), Przewodnik po Łęczycy i regionie tęczyckim, Towarzystwo Miłośników Ziemi Łęczyckiej, Towarzystwo Naukowe Płockie Oddział w Łęczycy, Urząd Miejski w Łęczycy, Starostwo Powiatowe w Łęczycy, Łęczyca 2005; www.swinicewarckie.com.pl.

${ }^{11}$ Ustawa z dnia 7 lipca 1994 r. Prawo budowlane (Dz.U. 2016, poz. 290, 961, 1165, 1250). 
Maria Konopnicka była jednym z najważniejszych przedstawicieli nurtu realizmu w polskiej literaturze. Nadal pozostaje najbardziej rozpoznawalną poetką w Polsce, a jej postać dla wielu jest symbolem patriotyzmu i wrażliwości na krzywdę ludzką. O skali jej popularności może świadczyć fakt, że jej imię nosi w Polsce blisko 800 ulic. Patronuje ona również kilkuset szkołom podstawowym (z czego przynajmniej 33 są to jednostki funkcjonujące na terenie województwa łódzkiego). Co więcej jest to postać, która w zasadzie wymagałaby ponownego odkrycia, ponieważ jej wizerunek wykreowany na użytek elementarnej i podstawowej edukacji jest z pewnością niepełny. Szereg wątków z jej biografii takich jak dążenie do wyzwolenia się ze zbyt ciasnych jej zdaniem ram towarzyskich, światopoglądowych i obyczajowych, potrzeba samostanowienia o swoim życiu osobistym i zawodowym, to zagadnienia zaskakująco aktualne także współcześnie. Najczęściej spotykaną materialną formą upamiętnienia znaczenia Marii Konopnickiej dla kraju są monumenty. Najbardziej znane pomniki znajdują się we Wrześni (według projektu Mieczysława Weltera, odsłonięty w 1977 roku), w Suwałkach (dwa monumenty według projektów Bohdana Chmielewskiego, odsłonięte w 1963 roku oraz w 2010 roku), w Kaliszu (Stanisław Horno-Popławski, 1969), w Gdańsku (Franciszek Duszeńko, 1977), w Krakowie (Antoni Hajducki, 1986), w Bydgoszczy (Krystyna Panasik, 1993) i w Warszawie (Stanisław Kulon, 1966). Natomiast na terenie kraju zachowało się zaledwie kilka budynków związanych z biografią Konopnickiej. Są to: dom w Suwałkach, w którym urodziła się przyszła poetka, mieści się muzeum jej imienia ${ }^{12}$, Muzeum Marii Konopnickiej w Żarnowcu ${ }^{13}$, znajdujące się w dworku będącym darem narodowym ofiarowanym Konopnickiej w 1902 roku oraz wspomniany już Dworek Marii Konopnickiej w Bronowie ${ }^{14}$. W tym kontekście niewątpliwą stratą dla krajowej kultury jest zaniechanie prób powstrzymania degradacji, tak cennego w skali regionu obiektu dziedzictwa kultury materialnej.

W rozważaniach przyszłych losów dworku Marii Konopnickiej w Gusinie należy brać pod uwagę trzy scenariusze rozwoju wydarzeń. Brak zabezpieczenia budynku przed niszczącym wpływem czynników atmosferycznych (zwłaszcza wód deszczowych i roztopowych) w krótkim czasie (szacowanym na 5-10 lat, biorąc pod uwagę aktualny stan techniczny dworku, rozmiar uszkodzeń i tempo ich powstawania) doprowadzi do całkowitej i bezpowrotnej degradacji. Niestety na chwilę obecną jest to scenariusz najbardziej prawdopodobny. Byłby to też finał zacierania autentycznych śladów obecności Marii Konopnickiej w regionie uniejowskim, zapoczątkowany jeszcze przez jednego z użytkowników dworku w Gusinie, który w trakcie prac porządkowych na strychu spalił nagromadzone tam w trakcie pobytu Konopnickich książki, gazety, dokumenty, rękopisy i inne „szpargały”, dziś z całą pewnością uznane za cenną spuściznę po poetce. Innym wariantem, który należy rozpatrzyć, jest kapitalny remont budynku. Bio-

\footnotetext{
${ }^{12}$ www.mk.muzeum.suwalki.pl

${ }^{13}$ www.muzeumzarnowiec.pl

${ }^{14}$ www.mariakonopnickawbronowie.pl
} 
rąc pod uwagę stopień zaawansowania i różnorodność współczesnych technik oraz technologii konserwacji obiektów budowlanych, nie ma przeciwwskazań dla tego typu przedsięwzięcia. Przeszkodą w tym przypadku nie byłby również brak kamienia budowlanego, ponieważ jest on nadal eksploatowany na potrzeby lokalne w niewielkim kamieniołomie w rejonie wsi Rożniatów i Czepów w gminie Uniejów. Odrębną sprawą jednak są koszty takich prac oraz poważna wątpliwość czy ich efekt spełni współczesne standardy pozwalające na użytkowanie obiektu jako budynku mieszkalnego. Zdecydowanie mniej kłopotliwe byłoby dążenie tą drogą, mając na celu jedynie poprawę i ustabilizowanie kondycji pustostanu lub użytkowanie sezonowe wyremontowanego dworku np. jako obiekt skansenowski, czy izba muzealna. Istnieje wreszcie możliwość rozbiórki obiektu, ale z zaplanowaną z góry jego odbudową. Przykładem takiej realizacji jest odbudowany w 1955 roku, a następnie zrekonstruowany już w XXI wieku dwór Mickiewiczów w Nowogródku, gdzie obecnie mieści się „Muzeum Adama Mickiewicza"15. Replika dworku w Gusinie mogłaby zostać wzniesiona już ze współczesnych materiałów budowlanych (skoro i tak od początku budynek był otynkowany), przy wiernym zachowaniu kształtu bryły i rozplanowania otworów okiennych i drzwi. Można by natomiast rozważyć zastosowanie miejscowego kamienia, jako wyeksponowanego materiału elewacyjnego, np. w przypadku wykończenia ryzalitu czy przybudówki gospodarczej. Stanowiłoby to jednoznaczne nawiązanie do historii obiektu, jak również do dziedzictwa lokalnego budownictwa wiejskiego regionu, bazującego na tym właśnie surowcu skalnym. Niniejsza praca ma charakter wstępnej oceny stanu zachowania dworku w Gusinie. Przy rozpatrywaniu ewentualnego remontu kapitalnego, a tym bardziej odbudowy budynku, w przypadku jego rozbiórki, niezbędne są dalsze, bardziej szczegółowe badania. Należy zwrócić uwagę, że istniejący materiał archiwalny odnoszący się do okresu, w którym budynek był jeszcze użytkowany, jest bardzo skromny. Sprowadza się do zaledwie do kilku, maksymalnie kilkunastu fotografii przedstawiających głównie frontową elewację z lat 50., 60., 70. XX wieku. Jedynie część z nich została opublikowana w wydawnictwach regionalnych ${ }^{16}$.

\section{Bibliografia}

Gorączko M., Gorączko A., Cechy regionalne w budownictwie na terenie gminy Uniejów, „Biuletyn Uniejowski”, t. 2, 2013.

Gorączko M., Gorączko A., Vernacular architecture and traditional rural landscape in new socio-economic realities - a case study from central Poland, „Bulletin of Geography. Socio-economic Series" 2015, No. 30.

Gorączko M., Gorączko A. , Raport z analizy potencjału turystyczno-kulturowego Lęczycy i powiatu tęczyckiego, „Turystyka Kulturowa” 2016, 5.

${ }^{15}$ www.mickiewicz-museum.narod.ru

${ }^{16}$ H. Sławińska, Maria Konopnicka w Bronowie i Gusinie, Wyd. Literatura, Łódź; Szymaniak A. 2003, Grodzisko: dzieje parafii św. Ap. Piotra i Pawła, Wyd. Koronis, Grodzisko-Bydgoszcz 2003. 
Gorączko M., Gorączko A., Raport z analizy potencjatu turystyczno-kulturowego powiatu poddębickiego, Turystyka Kulturowa 2016, 6.

Powiat Łęczycki - mapa turystyczna skala 1:60000, Starostwo Powiatowe w Łęczycy.

Sławińska H., Maria Konopnicka w Bronowie i Gusinie, Wyd. Literatura, Łódź 2003.

Stownik geograficzny Królestwa Polskiego i innych krajów stowiańskich 1890, Tom XI (Sochaczew-Szlubowska Wola).

Solarski B., Sęczkowska M., Prasnowska A. (red.), Przewodnik po Łęczycy i powiecie łęczyckim, Towarzystwo Miłośników Ziemi Łęczyckiej, Towarzystwo Naukowe Płockie Oddział w Łęczycy, Łęczyca 2000.

Szymaniak A., Grodzisko: dzieje parafii św. Ap. Piotra i Pawła, Wyd. Koronis, Grodzisko-Bydgoszcz 2003.

Szymczak J. (red.), Przewodnik po Łęczycy i regionie łęczyckim, Towarzystwo Miłośników Ziemi Łęczyckiej, Towarzystwo Naukowe Płockie Oddział w Łęczycy, Urząd Miejski w Łęczycy, Starostwo Powiatowe w Łęczycy, Łęczyca 2005.

Ustawa z dnia 7 lipca 1994 r. Prawo budowlane (Dz.U. z 2016 r., poz. 290, 961, 1165, 1250).

Wicher-Dysarz J., Dysarz T., Wstepna prognoza wptywu odmulenia rzeki Ner na warunki hydrauliczne jej koryta, „Acta Scientarium Polonorum, Formatio Circumiectus” 2010, 9 (3).

www.kultura.lodz.pl

www.mariakonopnickawbronowie.pl

www.mickiewicz-museum.narod.ru

www.mk.muzeum.suwalki.pl

www.muzeumzarnowiec.pl

www.swinicewarckie.com.pl

www.zamkilodzkie.pl

[Artykuł wpłyną: kwiecień 2017; akceptacja: czerwiec 2017]

\title{
TECHNICAL CONDITION OF MARIA KONOPNICKA'S COUNTRYSIDE MANOR IN GUSIN IN CONTEXT OF ITS POTENTIAL PRESERVATION
}

\begin{abstract}
Summary
A great potential in cultural tourism is connected to the places with a significant historical value, for example those connected to the biography of famous people. One of Poland's greatest poets of XIX/XXth century - Maria Konopnicka - spent several years in the village of Gusin, nearby Uniejów in Łódzkie Voievodship. The article presents the results of the deterioration evaluation of her landmarked countryside manor. Investigation of its technical state revealed that building is in really poor condition. The process of deterioration and occurrence of damages to the structure was partly a result of using local limestone as its main construction materials. That fact, study predicts, is of a key importance in the prospective restoration effort, which would be necessary for its further utilization.
\end{abstract} numents

Keywords: Maria Konopnicka, Gusin, degradation of building, protection of cultural mo- 